\title{
Identity, Nasab, and Kafaah in Marital Life: A Look into Indonesian Arab Women in Solo, Central Java, Indonesia
}

\author{
Nawiroh Vera ${ }^{1}$, Deddy Mulyana ${ }^{1}$, Lukiati Komala Erdinaya ${ }^{1} \&$ Nuryah Asri Sjafirah ${ }^{1}$ \\ ${ }^{1}$ Communication Faculty, Padjadjaran University, Bandung, Indonesia \\ Correspondence: Nawiroh Vera. E-mail: nawiroh.vera@budiluhur.ac.id
}

Received: January 26, 2018

Accepted: February 20, $2018 \quad$ Online Published: March 20, 2018

doi:10.5539/ass.v14n4p30

URL: https://doi.org/10.5539/ass.v14n4p30

\begin{abstract}
This research aims to reveal the identity of Indonesian Arab women in terms of nasab and kafa'ah marriage. To analyze the research finding the researchers use Social Practice theory from Bourdieu - Habitus and Doxa concept and the Communication Identity theory of Hecht. The lineage of the Arabs is patrilineal; therefore, the Arab men are more flexible in terms of choosing a mate. However, Arab women have to struggle hard if they are going to marry men from different groups. This research uses critical ethnographic methods, and the data is obtained through observations and interviews. The results show that the identity of Arab women is historically formed by Arab ethnic patriarchal culture from its home region of Yemen. The position of Solo Arab women as a subordinate group that is socially marginalized is due to the narrowness of women's space. Women are considered as a group with no extensive knowledge of the tradition of nasab and kafaah marriage.
\end{abstract}

Keywords: Arabic Woman, habitus, doxa, nasab identity, kafaah

\section{Introduction}

The people of Arab descendants in Indonesia known as Hadhrami (because their ancestors came from the city of Hadramaut, Yemen) consist of two major groups: Ba'alawy (Sayyid) and Sheikh (Masyaikh). The Sayyids and the Sheikhs have fundamental differences. Even the marriage between the Sayyids and the Sheikhs was strongly opposed. A boycott commonly occurs if a sharifah (nickname for a female sayyid) is married to a man of Sheikh's group. The most fundamental difference is the issue of descendence or heredity. Arab society is notoriously ethnocentric in viewing their tribes. The Sayyids are descended from Ali ibnu Abu Talib and Fatimah Azzahra, the daughter of the Prophet Muhammad SAW. Due to the fact that they are the descendants of Rasulallah, the ancestors of the Sayyid faction feel that they should keep the lineage by marrying among Sayyid fellows consisting of many clans. This is what they call a kufu (kafaah) / endogamy marriage.

Patriarchal culture adopted by the people of Arab descendence in Indonesia has an impact on male domination. The matter of nasab / family lineage or heredity is strongly defended in the social life of Arab ethnicity. The lineage of the Arabs is the patrilineal; therefore, Arab men are more flexible in terms of choosing a mate. However, Arab women have to struggle hard if they are going to marry men from different groups. In their effort to perpetuate the offspring based on clans, the Arabs prefer to marry their own ethnic fellows as their couples, and this is called as a system of nation endogamy marriage (marriage to ethnic fellow).

Arab women are muted and unable to articulate themselves well. The silencing does not occur explicitly or by force, but through everyday cultural practices - this is what Bourdieu calls Doxa: a kind of social order within a stable individual and bound with tradition, and there is a completely naturalistic and unquestioned power, so doxa resembles ideology. (Bourdieu, 2009, p. XXI).

In addition to silencing the identity of women as subjects, i.e. as an individual, she is bound to a social process that creates a woman as a 'subject' to herself and others. As Chris Barker argues that the conception we believe about ourselves can be called an identity, while the expectations and opinions of others form a social identity (Barker, 2004, p.169). What is meant by an individual is all social and cultural aspects. In the Arab ethnic groups where patriarchal culture is dominant, then it can be said that the identity of a woman both as a person or a group cannot be separated from the social identity and patriarchal culture.

Based on this background, the researchers are interested to examine the nasab or genealogical traditions in the nation endogamy marriage called $k u f u$ / endogamy marriage in the community of Arab Ethnic Groups in Solo, 
Central Java, Indonesia. This tradition is related to the right of women in determining their way through family that is through marriage. Women do not seem to be given the option to choose their desired mates. The domination of men that are very strong also makes Arab women dependent in actualizing themelves. Before marriage, the authority of girls' father is very strong, and after marriage, they have to obey their husband. For the purposes of the analysis, the researchers formulate the research problem as follows "How is the identity of Arab women in the tradition of civilization in a patriarchal Arab culture environment in Solo, Central Java, Indonesia?"

\section{Theoretical Framework}

\subsection{Communication Theory of Identity}

The identity of women in social positions in interacting and communicating with Arabs in Solo is another aspect that the researchers will study. For the purposes of analysis, the researchers use the theory of communication about identity. According to Michael Hecht and his colleagues (2005), in the theory of communication about identity there are three cultural contexts as follows:

Individual, communal and public - According to this theory, identity is the primary link between individuals and society, and communication is the link that allows this relationship to occur. Certainly, identity is a 'code' that defines one's membership in a diverse community. The code here consists of symbols, such as clothing and possessions; and words, such as oneself-description or objects that are usually said and the meaning of those words (In Littlejohn \& Foss, 2014, p. 131)

An identity is formed when a person is socially interacting with others in life. Someone obtains the views and reactions of others in social interaction; on the contrary, he shows a sense of identity by expressing himself and responding to others. The subjective dimension of identity is a personal feeling, while ascribed dimension is what others say about you. In other words, the personal identity consists of the meanings learned and what obtains. Then these meanings are projected to others whenever you communicate.

\subsection{The Social Practical Theory of Pierre F. Bourdieu}

Bourdieu said "Of all the oppositions that artificially divide social science, the most fundamental and most ruinous is the one that is set up between subjectivism and objectivism. The unanalyzed element in every theoretical analysis (whether subjectivist or objectivist) is the theorist's subjective relation to the social world and objective (social) relation presupposed by this subjective relation" (Bourdieu, 1990, p. 25).

The Practical Theory developed by Bourdieu explains the emphasis of subject involvement (community) in the process of cultural construction as a social practice closely linked to habits, capital and domains. Bourdieu's theory is driven by a desire to overcome what is mentioned as a false opposition between objectivism and subjectivism, or what he describes as, "the absurd opposition between individuals and society" (Bourdieu, 1993 in Adib, 2012, p. 5). 'Action' (practice) is the formation of (and simultaneously responses to) cultural rules and conventions. Bourdieu's social practice theory consists of several important concepts such as habits, fields, capital, and doxa.

Habitus is a society's routine attached to individuals in the form of an eternal disposition, or a well-trained capacity and a structured tendency to think, feel and act in a determinant way, which then guides them. Habitus is a cultural unconscious influenced by history and unconsciously perceived as something natural (Takwin, 2009, p. xviii).

Habitus is created through a social process, not by a lone individual, and not only leads to a lasting pattern that can be diverted from one context to another, but also shifts in relation to the specific context and over time. However Habitus 'is not fixed or permanent, and can be changed in unexpected situations or over long periods of history' (Navarro, 2006, p. 16)

The 'Patriarchal' culture positions women in the social structure of society. In the customs of Eastern cultures, especially Indonesia, women have always been subordinate to men in many ways as well as women of Arab ethnic in Indonesia. A subordinate position in this society has been formed naturally and internalized in a long time. Therefore, it has become a common assumption that women always come under men. How intelligent the women are, they have never been given any free maneuver in interpreting the traditional marriage of the same clan or family, or kufu/kafaah. The truth of the exegesis of the nasab, or kafaah marriage almost all refers to the opinions of the male interpreters.

According to Bourdieu, field is a network of relations between objective positions in a social order that is presented separately from individual consciousness and willingness (Takwin, 2009, p. xix). The field is not an 
intersubjective bond between individuals, but it is a sort of structured relationship and unconsciously organizes individual and group positions in a spontaneously formed society. Habitus enables people to live spontaneously in their daily lives and to engage with outside parties. In the process of interaction with outsiders, the field and the network of relationships of objective positions are formed. The field is a metaphor that Bourdieu uses to describe a structured and dynamic society with the power it contains. In the habitus of society groups, there are such domains like religions, culture, economy, socio-politics, and others.

Capital - The so-called capital by Bourdieu includes material objects (which can have symbolic values) and various 'untouchable' attributes, but they have cultural significance, such as prestige, status and authority (referred to as symbolic capital), as well as cultural capital (which are defined as tastes of cultural values and consumption patterns).

Bourdieu also makes the link between class and disposition "the dominant class is a relatively autonomous space, whose structure is defined by the distribution of economic and cultural capital among its members. Each class fraction is characterized by a particular distribution configuration that corresponds to a particular lifestyle, through intermediate habitus "(Bourdieu, 1984, p. 260).

The symbolic dominance of Bourdieu's thought brings up what he calls Doxa. Doxa is an unconscious, deep-rooted, fundamental, learned belief that is perceived as a self-evident universal, informing the actions and thoughts of an agent in the particular fields (Arismunandar, online article accessed on 27 November 2016 at 21.00).

Doxa shows how the dominant group can achieve, defend, and develop its power by playing a symbol that successfully enters the dominated mind, so they lose its critical attitude to the ruler. The controlled party sees itself equal to the ruler. They are oppressed, but never feel really oppressed because they live in doxa.

\section{Method}

This research uses the critical ethnographic method developed by Soyini Madison (2012) in which the main components of critical ethnography are factors such as full-oriented values, empowering communities by granting more authority, challenging the status quo, and concerning with power and control.

"Critical ethnography or what some have called the "new ethnography", must not only critique the nation of objectivity, but must also critique the nation of subjectivity as well" (Madison, 2012, p.16). Madison also said, "Critical ethnography begins with an ethical responsibility to address processes of unfairness or injustice within a particular lived domain" (Madison, 2012, p. 5).

Critical ethnography is a type of ethnographic research in which the authors are defending emancipation for marginalized groups (Thomas, 1993, in Creswell, 2014, p. 130). Critical researchers usually think and search through their research, advocating against inequality and dominance (Carspecken \& Apple in Creswell, 2014, p. 130).

Critical ethnographic methods attempt to provide moral judgments, social criticisms and offer solutions for the creation of equal rights. The researchers functions as an agent that rejects 'domestication'. Madison (2005: 5 in Kriyantono, 2016, p. 103) defines domestication as a process or action that makes a person, group, or society under the domination of certain parties. This domestication can occur coercively or in a subtle way, unnoticed by an individual, groups, or a certain community (like in the process of ideological hegemony). These subtle attempts are usually through the dissemination of communication messages containing the dominant party ideology. The society considers the messages as something neutral; containing the common good and apparently accepts them without criticizing.

This domestication can occur in the practice of nasab tradition in kufu marriage in the Indonesian Arab ethnic circles if the messages conveyed focus more on efforts to relate to religious texts such as verses of the Qur'an and hadith by manipulating the interpretation. This is potentially creating a false reality in the society, especially Arab women who unconsciously assume that the reality based on the texts of the religion is objective. To investigate such a reality we have used a qualitative approach.

This research approach is qualitative. Qualitative researchers speak a language of "cases and contexts." They emphasize conducting detailed examinations of cases that arise in the natural flow of social life. They usually try to present authentic interpretation that are sensitive to specific social historical contexts (Neuman, 2003, p. 139).

Qualitative research does not use the term 'population', but it is called a 'social situation' that consists of three elements: places, actors, and activities that interact in a synergy (Sugiyono 2015, p. 49). Such a social situation can be expressed as a research object that will be studied based on "what is happening" inside it. In the social 
situation or the object of this research, the researchers can deeply observe activities of Arab community (actors) that exists in the Town of Solo (place).

\subsection{Participant (Subject) Characteristics}

This research uses participant observation and interviews in obtaining data. The fieldwork lasted for almost a year and took place in 2017. The subjects of the research were the selected parties based on the consideration of the research needs. Subjects in research are often referred to as informants, i.e. people or parties who are subjected to the research and can provide information. The number of the informants in this research is 24 women and men of Arab ethnic in Solo who meet the certain criteria, and the researchers assume that they can provide data in order to answer the research questions. Criteria referred to is Arab ethnic from the group of Sayyid (firmly holds the ancestral traditions) on the tradition of nasab and the nation endogamy marriage, as well as Arab ethnic of the Sheikh group who does not really concern with nasab.

\section{Research Results and Discussion}

\subsection{Arab Ethnic Identity in the Tradition of Family Lineage and Endogamy Marriage}

Ego-ethnicity of Arab society is quite high in view of their tribe and clan. Social layers are formed by themselves in social life in the society. Arab Ethnics do not recognize the existence of social strata, but it happens in the reality. The most obvious example is the rejection by individuals, families, and communities to inter-ethnic marriages, even among the groups within the Arab ethnic itself.

The two Arab groups of the Sayyid and the Sheikh have differences, and the differences can be seen through the names of the clans. People outside of the Arab ethnic group may not be able to distinguish between the Sayyid and the Sheikh because in terms of physical characteristics they are the same. When viewed from the tradition run, some parts are the same, and some other parts are different. The difference lies in the schools that are believed and practiced in worship rituals, such as prayers, marriage, death, etc.

The Sayyid group has the highest resistance in terms of nasab and kufu marriage. This belief has become the habitus of both men and women and internalized in daily life. In the arena of culture and religion, the ethnic identity of the Arab Sayyid in the nasab and kufu marriage is reproduced as an issue of 'the Prophet's desire' conducted by the elite of the Arab ethnic in order to perpetuate the power of the nasab tradition and kufu marriage among the Sayyid.

The identity of Sayyid and Sharifah is reflected in calling of names and titles. Habib is synonymous with Sayyid although literally habib means lover. Sayyid or Syarifah of Arab identity with the nasab refers to the descendants of the Prophet. 'Ipah' is a call for a Sayyid girl, and 'Ye' is a call for a Sayyid boy. The verbal call to the Sheikh class is 'Wan' for both men and women.

The strength of Arab ethnic identity is in nasab and kufu marriage through the interference of ethnic elites such as religious figures, clerics, and leaders that exist in each region, also in the headquarters. By using the field of religion and culture, this elite group that usually consists of men frequently uses symbolic violence in practice. Symbolic violence is essentially the imposition of categories of thought and perception of dominated social agents, who then regard the social order as something 'fair'. This is the union of the unconscious structure, which tends to repeat the structures of actions of the dominant party. The dominant party then sees the position of the dominant party as the 'right'. For example, they assume that according to the religious teachings that the so-called kufu marriage is a marriage of the same group that is Sayyid and Syarifah.

As a result, the young Arabs in determining their soul mates feel that it is compulsory to seek them from their own kind, so they live in doxa according to the Bourdiue theory. They accept this tradition as something normal, true, and must continue to be guarded or preserved and even it becomes obligatory to keep the nasab. The group's intervention in defending the nobles exists everywhere including $A r$-Rabithah that heavily informs about hereditary forgeries, and the advice to parents to be careful. The advice is more emphasized for girls, because men can marry whomever and the family lineage will never lose.

The Sheikh group is rather loose in viewing endogamy marriage because this group views family lineage not because of its specificity and the exclusiveness of being the descendants of the Prophet. They maintain endogamy marriage due to cultural similarities and maintain their ethnic identity by getting married to other ethnic groups whose religion is the same. The Sheikh group also has a clan but has no family tree; therefore, they are rather loose in maintaining the endogamy marriage.

\subsection{Identity of Women as a Subordinate Group}

In women's patriarchal eyes, women are positioned as subordinate. In the eyes of feminism, women become 
marginal figures and second-class citizens in their life. Women are limited in their educational, social and religious rights. The presence of women in the dynamics of life does not attain a balanced position with men because there is still a unilateral interest perpetuating patriarchal culture among the Arab ethnic groups.

Arab women are still conditioned in domestic territory; therefore, high education for women is not really concerned by the parents, and they even tend to limit that the girls do not need to go to college. No matter how educated they are, women still have to be a housewife whose primary job is to take care of her husband and children. Education in Arab ethnic circles especially women is limited in space. Arab elders in Solo almost certainly send their daughters to schools that are managed by Arab ethnic groups, such as Diponegoro Islamic Education Foundation affiliated with the Sayyid and Al-Irsyad Foundation affiliated with the Sheikh. Yet if it refers to Islam as the foundation and philosophy of life of most Arab ethnic groups, there is absolutely no doctrine that distinguishes positions between women and men in the domestic realm as well as in the public sphere. The researcher confirmed to an expert on Islam and Arab culture, Haidar Bagir, who stated that:

"There is nothing in the teachings of Islam that distinguishes it. Both the Qur'an and Hadith do not say that women are only in the domestic realm and men in the public sphere. The Hadith clearly states that a husband should not impose his wife's household affairs, even the husband is required to find a maid".

The habit of blending with the same ethnic fellows makes the children of Arab ethnic more comfortable with this condition, so it has become habitus. The culture that marginalizes the role of education makes Arab women increasingly powerless. Arab women are increasingly silenced because they feel they do not have the capacity to express their opinions. Some of the women who have begun to open their minds have started to try to convey their ideas, especially about the needs for education both for men and for women because education can change the situation to be better.

Through the movement of some educated women, some parents' mindsets regarding the importace of education have begun to open. The identity of Arab women influences the worldview of culture and tradition that has been accepted as habitus and doxa. The identity of being an educated female amongst ethnic Arabs is formed after socially interacting with others in their lives. The average level of education of Arab women is high school where the students mostly come from their own ethnic group or minority, so that those who have the opportunity to go to college start to mix with different ethnics with different cultures. This is in line with the opinion of Michael Hecht (2014, p. 131) "Someone gains a view and reactions of others in social interaction and in reverse showing a sense of identity by expressing themselves and responding to others." Discussing identity means examining the side of personal life and social life, and in this case, with the lives of women of Arab ethnic origin in Solo, is adapted to the layer of identity as formulated by Hecht:

a. Personal Layer - The identity consists of various feelings and ideas of oneself, who and what are the Arab ethnic women like.

b. Enactment layer - It is the others' knowledge of oneself based on deeper symbols about someone's identity interpreted by others through the Arab women's communication performance.

c. Relational layer - This identity is the linkage between the individual of Arab women and other individuals, where the identity is formed and even constructed by the environment. Solo culture that is patriarchy causes Arab women in Solo to perpetuate patriarchy culture. In this layer, women have a position under men in terms of issuing religious orders, issuing opinions, and women's opinions are only heard by women groups, and the men who want to listen to the women opinions are very few.

d. Communal layer - Identities that are tied to larger groups or cultures - This level of identity is very strong in Arab culture, in view of the position of others seen from the lineage called nasab. The position of social status and the economic status of education level is less concerned. The identity of the Sayyid group is hierarchically considered the highest and the most exclusive.

\subsection{Analysis Based on Bourdieu's Social Practice Theory}

Arab community in Solo lives in groups in a certain area in Pasar Kliwon (namely the district area in the solo city), so it completely assures the views of life in the social environment like family and community. The social space of the Solo Arab community became the arena of Arab women in interacting, communicating with each other. Messages communicated by parents, leader figures, religious figures are so naturalized that increasingly form subjective structures and become their habitus.

In the position of Solo Arab women, the strength of religion and culture makes women take for granted all of the explanations in the name of religion without daring to question its validity. This condition is called Doxa, which shows how the dominant group (ruler, clerics, religious figures, and parents) can achieve, defend, and develop its 
power by playing symbols that successfully enters the dominated mind, so they lose their critical attitude to the ruler. The controlled party sees itself equal to the ruler. Arab women seem to live in Doxa, their position is subordinated, but they never feel that way.

The cultural unconsciousness of Solo Arab women is due to symbolic violence practices of dominant groups that in this case are parents (father and mother), leaders, clerics, religious leaders. This dominant group uses the field of religion as moral claims. In addition to the field of religion, sometimes the cultural field also plays an important role. The cultural field is seen in the social practices of life among the Solo Arab ethnic who apply patriarchal culture. Men have a higher position than women; therefore, men are the ones who control women in all aspects of life. The position of wife and child is more sub-ordinate than motherhood. The girls who are considered righteous are those who are obedient to their parents. Father is the main authority at home, so anything he orders is something that has to be done. If it is refused, the children will be considered disobedient. From some interviews and observations in the field, the researchers today see that some Arab ethnic families have been somewhat open in terms of communication with children and wives, especially in determining the future of children in fostering families. However, subtly the will of the parents is still dominant. If a child does not like the prospective husband who is selected by his parents, then as much as possible the parents and the family will persuade and seduce the girl in every way until the child finally gives up.

In the interviews with the parents, they said that it is true that parents look for a mate for their daughter, but that the child is still given the opportunity to see her parents' choice, which ultimately she would approve. By contrast, in the interviews with the girls, they said that they are mostly forced to get married - because of the fear of sin against parents. Other opinions say that the most importantly their parents are happy even though she did it heavy-heartedly.

A wife who is considered righteous is obedient to her husband. The totality of obedience is constructed by patriarchal Arab culture, and continues to be perpetuated using the religious field by using symbolic capitals through unilateral claims without giving opportunities for a dialogue.

The argument underlying the opinion that the wife is obliged to obey the husband is for example taken from the words of Allah in the holy book Al-Qur'an, verse An-Nisa, section 34, which reads: MEN SHALL take full care of women with the bounties which God has bestowed more abundantly on the former than on the latter, and with what they may spend out of their possessions. And the righteous women are the truly devout ones, who guard the intimacy which God has [ordained to be] guarded (Asad, 2017, p. 166)

Women who try to question the explanation of the verse's interpretation are sometimes considered as going against the current; consequently, they choose to remain silent, and the clerics or scholars who try to interpret differently sometimes experience the same condition. Especially about the position of husband and wife is truly not only among Arabs who think the same way. Most Muslims acknowledge and agree with that opinion. The concern of the researchers is that almost all opinions are raised by men while women are increasingly silenced, the opportunity to discuss this issue is not provided.

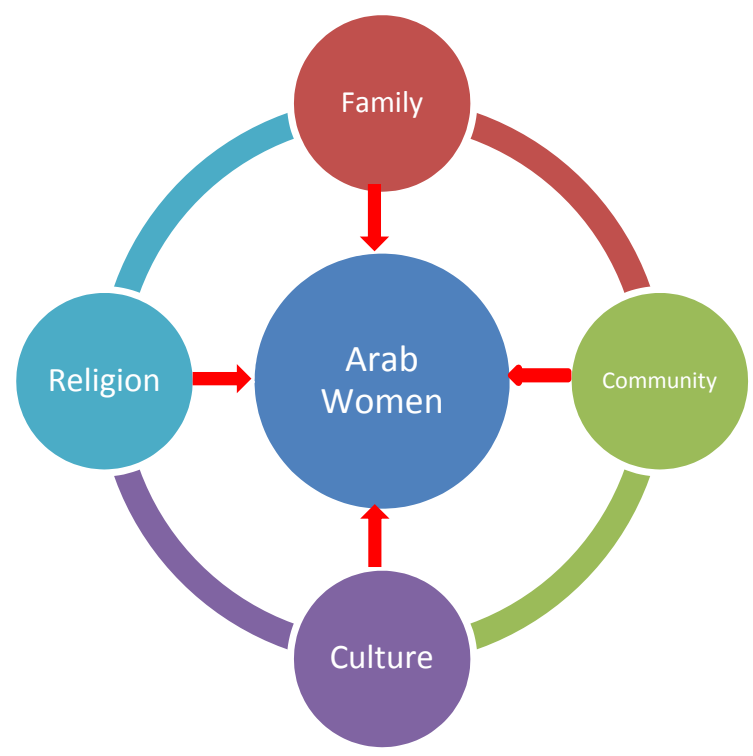

Figure 1. The relationship between culture-religion-individual-community (Processed based on field data) 
The process of silencing is persistent and has become a kind of ideology among Arab ethnic groups as if women are not worthy to speak out, especially in claiming their rights in social life both within the family and in the social environment of the community. In line with the main idea of the silent group theory, marginalized group members are silenced and regarded as non-fluent speakers. Arab women are considered not to master the science of religion better than men, and the main reason is because women tend to be emotional especially when it comes to women's rights. Women's opinions, especially those considered critical, will be regarded as an opinion without foundation and made up, just putting forward emotion, and so forth.

Arab women in particular and Muslim women in general have been the object of male sovereignty perpetuated in the patriarchal culture, by interpreting the religious texts of both the Qur'an and the hadist in a misoganist way.

The picture above illustrates the relationship between individuals, communities, and cultures influenced by religion and patriarchal systems that color women's lives in the Arab community of Solo City.

Arab women in Solo City who became the subject and focus in this research based on historical exploration are the figures that are considered important in the family of Arab ethnic groups, but the position of women is distinguished based on their roles, as a mother, as a wife, and as a child. The differences in women's position based on the research findings are related to the living conditions within Arab ethnic groups who still hold the principles and traditions of their ancestors. The patriarchal culture of the Arabs associated with the religious postulates greatly affects the life of Arab women today. Male dominance persists and has been considered normal by most women themselves.

\section{Conclusion}

Based on the analysis and research discussion on the identity of Arab women in viewing the family lineage tradition and endogamy marriage the conclusion is obtained as follows. First (1) the position of Solo Arab women as subordinate groups is socially marginalized due to the limited space of women's movement. Women are regarded as a group with no extensive knowledge of the tradition of family lineage / nasab and endogamy / $k a f a a h$ marriage. This is proven by the absence of female figures who are proficient in the science of nasab, science of interpretation, and science of hadith. Women only follow the fatwa of scholars and male-dominated traditional leaders. If there is a woman who is knowledgeable about this, then she is considered as a dissident even by the group of women themselves. The hegemony of patriarchal ideology has been firmly entrenched in Arab women, and they accept this as the truth.

Second (2) the identity of Arab women has been formed historically by Arab ethnic patriarchal culture from its home region of Yemen. Historically the life of Arab women is dominated by Arab cultural traditions and norms. Arab culture is patriarchal culture, and nasab tradition is highly preserved. The life from the origin country in the form of tribal ties from the time of the Prophet Muhammad continued to be brought until they live abroad including in Indonesia. The existence of various groups of family derived through the father's path reinforces the position of men as the dominant group. This tradition acts as a form of blurring the identity of Arab women. Women cannot continue forming their offspring, but women themselves are the ones who must submit to the endogamy marriage. The identity of women is formed through a cultural capital - in this matter, language is taking part as an expression of resistance and rejection. Educated women among both Arab ethnic groups keep attempting to change perceptions through cultural communication in their children in the hope that the next generation will not be trapped in the unbalanced tradition.

\section{References}

Adib, M. (2012). Agen dan Struktur dalam Pandangan Pierre Bourdieu. Jurnal BioKultur, 1(2), 91-110. Surabaya.

Asad, M. (2017). The Messege of the Quran. Bandung: Mizan.

Barker, C. (2004). Cultural Studies. Kreasi Wacana, Yogyakarta. https://doi.org/10.4135/9781446221280.n53

Bourdieu, P. (1984). Distinction. Routledge: Kegan \& Paul.

Bourdieu, P. (1990). The logic of Practice. Translate by Richard Nice. California: Stanford University Press.

Bourdieu, P. (2009). Critical Perspective. The University of Chicago.

Creswell, J. W. (2014). Penelitian Kualitatif dan Desain Riset. Yogyakarta: Pustaka Pelajar.

Hecht, M. L., Warren, J., Jung, J., \& Krieger, J. (2005). Communication theory of identity. In W. B. Gudykunst (Ed.), Theorizing about intercultural communication (pp. 257-278) Newbury Park, CA: Sage. 
Kriyantono, R. (2015). Public Relations, Issue \& Crisis Management. Jakarta: Prenada Media Group.

Littlejohn, Stephen dan Foss, \& Karen, A. (2014). Teori Komunikasi. Jakarta: Salemba Humanika.

Madison, S. (2012). Critical Ethnography, Methodos, Ethics, and Performance, second edition. USA: Sage Publications.

Mohammad, A. (2012). Agen dan Struktur dalam Pandangan Piere Bourdieu. BioKultur, I(2), 95.

Navarro, Z. (2006). In Search of Cultural Intepretation of Power. IDS Bulletin, 37(6), 11-22. https://doi.org/10.1111/j.1759-5436.2006.tb00319.x

Neuman, W. L. (2003). Social Research methods-Qualitative and Quantitative Approaches. USA: Pearson Eduction Inc.

Sugiyono. (2015). Memahami Penelitian Kualitatif. Bandung: CV Alfabeta.

Takwin, B. (2009). Ranah= Praktik: Pengantar Paling Komprehensif Kepada Pemikiran Pierre Bourdieu. Yogyakarta: Jalasutra.

West, R., \& Turner, L. H. (2010). Pengantar Teori Komunikasi. Jakarta: Salemba Humanika. Retrieved From http://satrioarismunandar6.blogspot.co.id/2009/05/pierre-bourdieu-dan-pemikirannya.html

\section{Copyrights}

Copyright for this article is retained by the author(s), with first publication rights granted to the journal.

This is an open-access article distributed under the terms and conditions of the Creative Commons Attribution license (http://creativecommons.org/licenses/by/4.0/). 